\title{
Analysis of financial management for decision making in medium-sized enterprises in Ciudad Juarez, Chihuahua
}

\section{Análisis de la gestión financiera para la toma de decisiones en las medianas empresas de Ciudad Juárez, Chihuahua}

\author{
MEJÍA-HERNÁNDEZ, Marisela*†, CASTILLO-GALEANA, Abelardo, DURÁN-ORTIZ, Martín Joel \\ and VEGA-MARQUEZ, Fátima
}

Universidad Tecnológica de Ciudad Juárez, Av. Universidad Tecnológica \#3051, Col. Lote Bravo II, C.P. 32695, Cd. Juárez, Chihuahua. Universidad del Caribe, Mza. 1, Lote 1, SM.78. Fracc. Tabachines, C.P. 77528, Cancún, Quintana Roo.

ID $1^{\text {st }}$ Author: Marisela Mejía-Hernández / ORC ID: 0000-0002-6108-6659, Researcher ID Thomson: S-8723-2018

ID $1^{\text {st }}$ Coauthor: Abelardo Castillo-Galeana / ORC ID: 0000-0002-6690-1691, arXiv Author ID: 2802584

ID $2^{\text {nd }}$ Coauthor: Martin Joel, Durán-Ortiz / ORC ID: 0000-0001-9359-5311, Researcher ID Thomson: V-7842-2019

ID $3^{\text {rd }}$ Coauthor: Fátima, Vega-Márquez / ORC ID: 0000-0002-8745-7489, arXiv Author ID: 2798767

DOI: $10.35429 /$ JMPC.2019.15.5.39.46

Recibido March 26, 2019; Aceptado June 28, 2019

\begin{abstract}
The objective of this research was to analyze the financial management in medium-sized enterprises in Ciudad Juarez, Chihuahua. For this, a quantitative methodology of descriptive non-experimental transactional design was used. Medium-sized businesses from the commercial and industrial sectors, established in Ciudad Juarez, Chihuahua, were considered as the unit of analysis. 87 businesses were identified with these characteristics. The fieldwork was completed with 31 medium-sized businesses, a questionnaire validated by experts was implemented and applied to the general administrators of each business. The results show that medium-sized businesses have an efficient financial management due to their low level of debt and completion of investment projects, however, these projects are primarily financed by partner contributions and accumulated profits. Thus, to improve the financial management in medium-sized businesses external financing is recommended through bank loans or the stock exchange market, likewise, the financial resources obtained should be allocated mainly for investment projects previously analyzed.
\end{abstract}

Financial management, Decision making, mediumsized enterprises

\begin{abstract}
Resumen
El objetivo de esta investigación fue analizar la gestión financiera en las medianas empresas en Ciudad Juárez, Chihuahua. Para ello, se utilizó una metodología cuantitativa, de diseño no experimental transeccional descriptivo. Se consideró como unidad de análisis a medianas empresas de los sectores comercial e industrial, establecidas en Ciudad Juárez, Chihuahua. Se identificaron 87 empresas con estas características. El trabajo de campo se realizó con 31 medianas empresas, se utilizó un cuestionario validado por expertos, el cuál fue aplicado al administrador general de cada empresa participante. Los resultados obtenidos muestran que las medianas empresas realizan una gestión financiera eficiente ya que su nivel de endeudamiento es bajo y realizan proyectos de inversión, sin embargo, estos proyectos son financiados principalmente por aportaciones de los socios y las utilidades acumuladas. Por lo tanto, para mejorar la gestión financiera en las medianas empresas se recomienda el financiamiento externo a través de préstamos bancarios o del mercado de valores, así mismo, los recursos financieros obtenidos deben destinarse principalmente a proyectos de inversión previamente analizados.
\end{abstract}

Gestión financiera, Toma de decisiones, medianas empresas

Citation: MEJÍA-HERNÁNDEZ, Marisela, CASTILLO-GALEANA, Abelardo, DURÁN-ORTIZ, Martín Joel and VEGAMARQUEZ, Fátima. Analysis of financial management for decision making in medium-sized enterprises in Ciudad Juarez, Chihuahua. Journal of Microfinance Planning and Control. 2019, 5-15: 39-46

\footnotetext{
* Correspondence to Author (email: marisela_mejia@utcj.edu.mx)

$\dagger$ Researcher contributing first author.
} 


\section{Introduction}

MSMEs represent the highest percentage of companies in Mexico, however, they have a survival of 12 to 24 months, with a profitability of 5 to $6 \%$ and a cost of $12 \%$ per year to acquire bank capital (BANXICO, 2015).

In the state of Chihuahua there are 124,219 economic units, of which 123,519 , that is, more than $99 \%$ are MIPYMES, companies with a number of employees below 250. While in Cd. Juarez, Chihuahua there are 41,109 economic units of the which $99 \%$ are MSMEs (INEGI, 2019).

According to the National Commission for the Defense of Users of Financial Services (CONDUSEF, 2015), MSMEs present various problems related to poor administration and financial management, which causes these economic units to have a short period of existence. Rodríguez (2016), points out that financial management in MSMEs is characterized by insolvency and low liquidity, as a result of ineffective financial policies or by the ignorance of the owner or manager regarding the proper management of their resources.

Castillo and Ceballos (2014), suggest that MSMEs retain a culture in which they seek to finance themselves through personal loans or banking institutions, however, the products offered by these institutions generate high financing costs and difficulty in obtaining them due to the requirements that companies must meet.

When MSMEs require financing, they can opt for a banking or non-bank one through government institutions, in both cases the presentation of an investment project is necessary, the credit institutions require formality and presentation of the project so that it is feasible to obtain the credit (Castro, 2017).

According to Gonzales and Quizhpe (2012), a company to grow needs financing and increases sales, and to achieve this, it requires investments in accounts receivable, inventories and fixed assets. In the short term, this financing can be derived from additional sales, as well as retained earnings. The above is achieved with efficient short-term financial administration.
Regarding medium-sized companies, their importance in the country is that they contribute $25 \%$ to $40 \%$ of the Gross Domestic Product (GDP) considering collateral added value (HSBC, 2017). In 2014 they employed $3,029,362$ workers, which represents almost $16 \%$ of the total population employed in the country (González, 2015).

The medium-sized companies, due to their characteristics in terms of income generation and employed personnel, are forced by their level of operations to have effective internal controls, detailed accounting records and greater fiscal commitments. Therefore, they require effective financial management.

The purpose of financial resources management is to obtain resources (either by capital contributions or credit), their correct management and application, as well as efficient coordination of working capital, investments and results, to make sound decisions (Perdomo, 2008).

An alternative option to obtain financial resources is through the Stock Market, where companies, credit institutions and government agencies offer financial instruments among the investing public, who acquires them through financial intermediaries (BMV, 2019).

According to Nava (2009), the analysis of financial management allows identifying the economic and financial aspects that show the conditions in which a company operates with regard to the level of liquidity, solvency, indebtedness, efficiency, performance and profitability, facilitating the taking of managerial, economic and financial decisions in business activity.

Analyzing the financial management of medium-sized companies will provide best practices that will contribute to improving their performance and encouraging their growth.

Therefore, the objective of this research was to analyze the financial management of medium-sized companies in the commercial and industrial sectors in Ciudad Juárez, Chihuahua. 


\section{Methodology}

The nature of the research was quantitative, descriptive non-experimental transectional design. The study variable was financial management and the indicators considered for its measurement were: financial performance, financial structure, use of information technologies, financial decision making, longterm financial administration and short-term financial administration.

The investigation was carried out in Ciudad Juárez, Chihuahua in the months of June to September 2018.

The information collection was carried out through the survey method, a questionnaire was administered that was designed considering the existing literature as reference and validated by a group of experts. The questionnaire was divided into two sections, the first one included general data and the second section consisted of 15 dichotomous questions and 10 closed multiple-choice questions that addressed the indicators of the variable financial management. It was considered as a unit of analysis for medium-sized companies in the commercial and industrial sectors, established in Ciudad Juárez, Chihuahua. 87 companies with these characteristics were identified.

For this, the database of the National Institute of Statistics and Geography (INEGI) was taken as a sampling frame. Considering this number of companies, it was proposed to make a census with the intention of including all of them in the study. The field work was carried out with 31 companies that met the characteristics required for this investigation. In each participating company the questionnaire was applied to the general administrator. The information collected was processed and analyzed using the statistical software SPSS version 24 .

\section{Results}

This section presents the socio-labor indicators, and the results of the indicators of the variable financial management.

\section{Socio-labor indicators}

31 medium-sized companies participated in this research, of which $52 \%$ belong to the commercial sector and $48 \%$ to the industrial sector. The two sectors mentioned are those that group the largest number of medium-sized companies in Ciudad Juárez, Chihuahua.

Table 1 shows the distribution by seniority and sector of the companies participating in the study. The results show that $60 \%$ of medium-sized companies in the commercial sector and $63 \%$ of those belonging to the industrial sector are between 6 and 15 years old.

\begin{tabular}{|l|r|r|r|}
\hline \multicolumn{4}{|c|}{ Sector } \\
\hline Antiquity (years) & Comercial & Industrial & Total \\
\hline 0 to 5 & $\%$ & $\%$ & $\%$ \\
\hline 6 to 10 & 13 & 12 & 13 \\
\hline 11 to 15 & 53 & 44 & 48 \\
\hline 16 to 20 & 7 & 19 & 13 \\
\hline 21 and more & 0 & 6 & 3 \\
\hline Total & 27 & 19 & 23 \\
\hline
\end{tabular}

Table 1 Age and sector of medium-sized companies Source: Self Made

\section{Financial performance}

Table 2 shows that $94 \%$ of the respondents affirm that in the company a financial management is carried out in which the financial statements are audited, analyzed and made projections that are subsequently reviewed against the results obtained. While $6 \%$ state that the above is not fulfilled. It is important to mention that $16 \%$ of the participants in the sample indicate that the financial statements are not audited by an internal control area.

\begin{tabular}{|c|c|c|}
\hline & Yes & \\
\hline Question & $\%$ & \\
\hline $\begin{array}{l}\text { Are the financial statements audited by an } \\
\text { internal control area? }\end{array}$ & 84 & 16 \\
\hline $\begin{array}{l}\text { Is an analysis of the financial statements } \\
\text { made to know their liquidity, operational } \\
\text { efficiency, solvency and profitability? }\end{array}$ & 97 & 3 \\
\hline $\begin{array}{l}\text { Are annual projections of sales, costs and } \\
\text { expenses made? }\end{array}$ & 97 & 3 \\
\hline $\begin{array}{l}\text { Are projections reviewed against the } \\
\text { actual results of the performance } \\
\text { obtained? }\end{array}$ & 97 & 3 \\
\hline Average & 94 & 6 \\
\hline
\end{tabular}

Table 2 Financial performance Source: Self Made 
Figure 1 shows that $74 \%$ of respondents believe that the financial performance of the company in the last 5 years is satisfactory, while $23 \%$ maintain a neutral position and $3 \%$ consider that the company has had a poor performance.

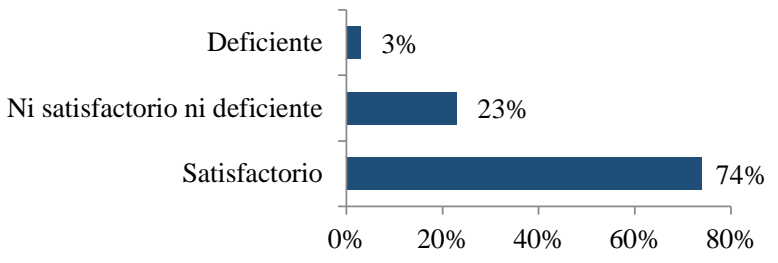

Graphic 1 Financial performance of the company in the last 5 years

Source: Self Made

\section{Financial structure}

With respect to the financial structure indicator, figure 2 shows that in $90 \%$ of the companies participating in this study the assets that come from external financing are in a range of 0 to $49 \%$ with respect to the total of their assets. While in $10 \%$ of companies the assets acquired with external financing are between a range of $50 \%$ and greater than $60 \%$.

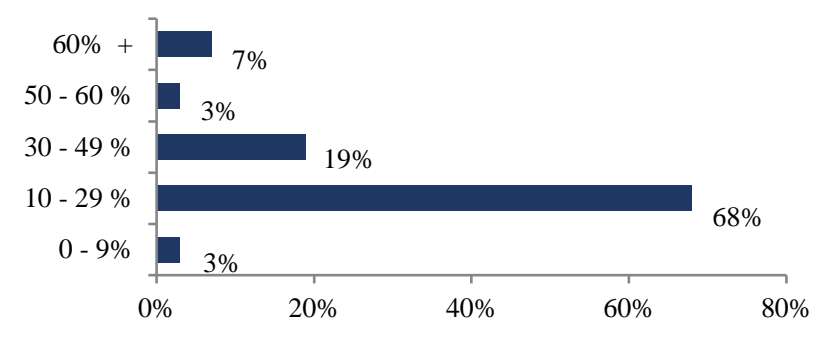

Graphic 2 Assets from external financing Source: Self Made

\section{Use of information technologies}

Table 3 shows that $84 \%$ of respondents state that the company has software for financial management and $14.5 \%$ mention that there is no support software.

\begin{tabular}{|l|c|c|c|}
\hline \multicolumn{1}{|c|}{ Question } & Yes & No & ND \\
\hline $\begin{array}{l}\text { Does the company have any software } \\
\text { for financial management? }\end{array}$ & 81 & 19 & 0 \\
\hline $\begin{array}{l}\text { Does the company have a computer } \\
\text { system for inventory management? }\end{array}$ & 87 & 10 & 3 \\
\hline \multicolumn{1}{|c|}{ Average } & 84 & 14.5 & 1.5 \\
\hline
\end{tabular}

Table 3 Use of information technologies Source: Self Made

\section{Information management}

Table 4 shows that $100 \%$ of respondents agree that the company uses the information in the financial statements for decision making, and 93\% of the participants indicate that the accounting and financial information has been available when it has been required to obtain credits. While $7 \%$ evidence the lack of information.

\begin{tabular}{|l|c|c|}
\multicolumn{1}{|c|}{ Question } & Yes & No \\
\hline $\begin{array}{l}\text { Is the information in the financial } \\
\text { statements used to make investment and / } \\
\text { or financing decisions? }\end{array}$ & 100 & 0 \\
\hline $\begin{array}{l}\text { Has accounting and financial information } \\
\text { been available to facilitate credit? }\end{array}$ & 93 & 7 \\
\hline
\end{tabular}

Table 4 Information management Source: Self Made

\section{Financial decision making}

Figure 3 shows that $39 \%$ of the companies participating in this study mention that they do not currently have any type of financing, 39\% obtain financing from partners, $10 \%$ are financed by banks and suppliers, 6\% obtain supplier financing, $3 \%$ has bank financing and the remaining $3 \%$ obtained financing from banks and partners.

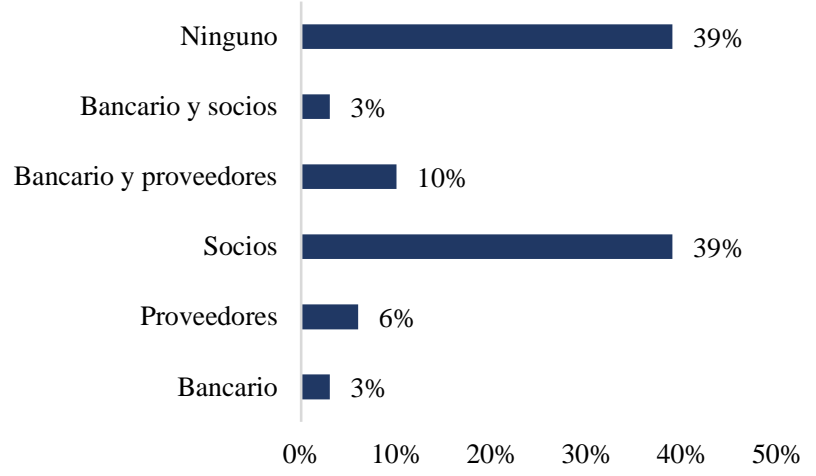

Graphic 3 Current financing Source: Self Made

The results in graph 4 show that of the total of companies that obtained some type of financing, $80 \%$ allocated the resources obtained to investment projects, $10 \%$ for the payment of debts and the remaining $10 \%$ for various purposes. 


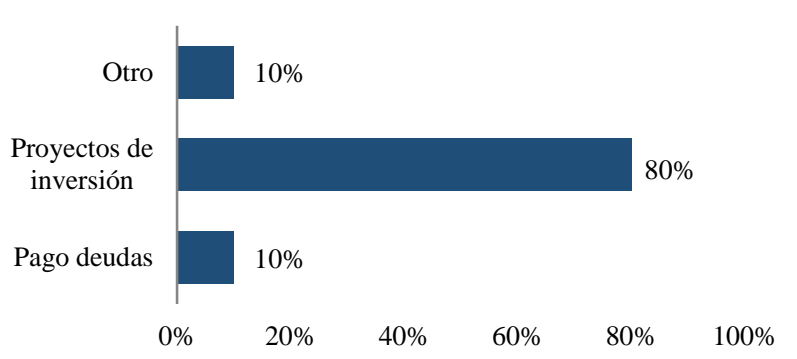

Graphic 4 Use of financing Source: Self Made

Figure 5 shows that in $84 \%$ of the companies surveyed the main partner and / or owner are the ones who make the financial decisions, in $10 \%$ it is the administrator, in $3 \%$ the main partner, owner and / or administrator and in the remaining $3 \%$ the counter.

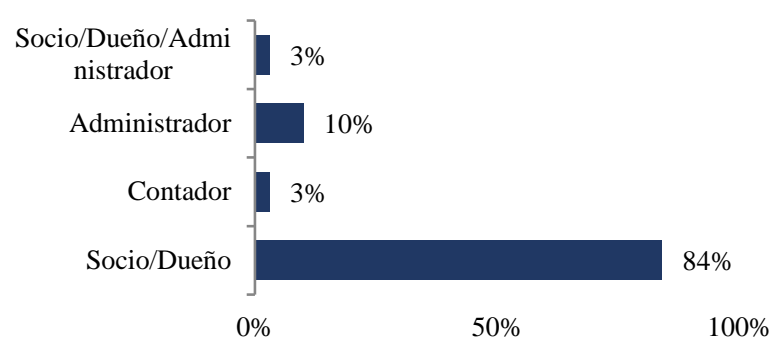

Graphic 5 Financial decision making Source: Self Made

Figure 6 shows that $81 \%$ of the companies surveyed make financial decisions based on the available information, while $16 \%$ is based on experience and the remaining $3 \%$ on intuition.

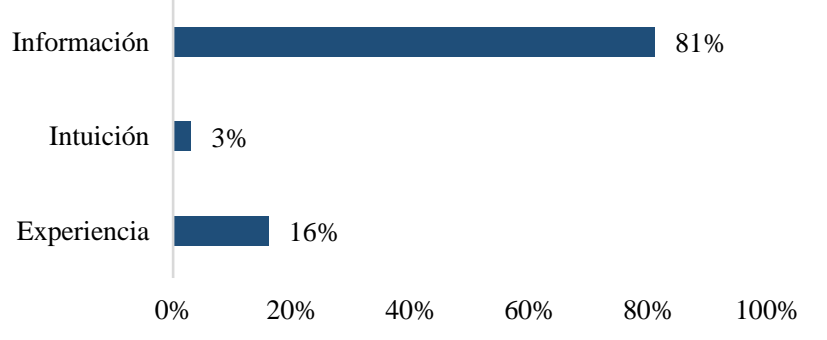

Graphic 6 Approach to financial decision making Source: Self Made

\section{Long term financial administration}

Table 5 shows that $68 \%$ of the companies participating in this research claim to have carried out a long-term investment project in the last 5 years, while $32 \%$ responded negatively.
On the other hand, 39\% of companies indicate that they currently have a long-term investment project and $61 \%$ currently do not have an investment project. $89 \%$ say they evaluate the financial cost of the various financing options, while $11 \%$ mention that they do not perform this evaluation.

\begin{tabular}{|l|c|c|}
\multicolumn{1}{c}{ Question } & Yes & No \\
\cline { 1 - 3 } & \multicolumn{2}{c|}{$\%$} \\
\hline $\begin{array}{l}\text { Has the company had long-term } \\
\text { investment projects in the last 5 years? }\end{array}$ & 68 & 32 \\
\hline $\begin{array}{l}\text { Does the company currently have a long- } \\
\text { term investment project? }\end{array}$ & 39 & 61 \\
\hline $\begin{array}{l}\text { Is the financial cost of the various } \\
\text { financing options evaluated? }\end{array}$ & 89 & 11 \\
\hline
\end{tabular}

Table 5 Long term investment projects Source: Self Made

Graph 7 shows that of the total number of companies that currently have a long-term investment project, $46 \%$ indicate that resources are invested in research and development, $38 \%$ invest resources in expansion, $8 \%$ in fixed assets and $8 \%$ remaining in various activities.

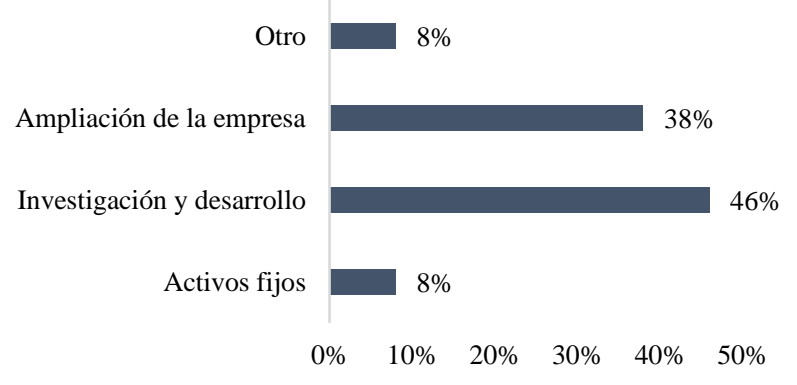

Graphic 7 Investment projects Source: Self Made

Figure 8 shows that of the total number of companies that have developed a long-term investment project in the last 5 years, $79 \%$ have considered the completion of the project taking as reference that the products present a competitive advantage, $16 \%$ market growth, while 5\% take into account the existence of few competitors in the market.

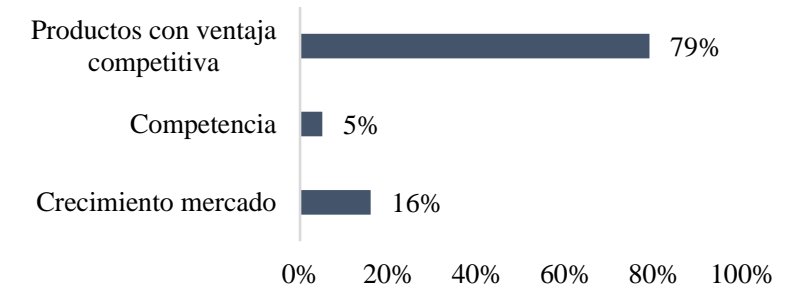

Graphic 8 Factors considered when conducting an investment project

Source: Self Made 
According to the results presented in figure 9 , of the total number of companies that have developed a long-term investment project, $30 \%$ of the companies carry out a technical study, $25 \%$ a financial study, $25 \%$ a market study, $15 \%$ carry out a study considering the technical, financial and market aspects, while $5 \%$ carry out a technical and financial study.

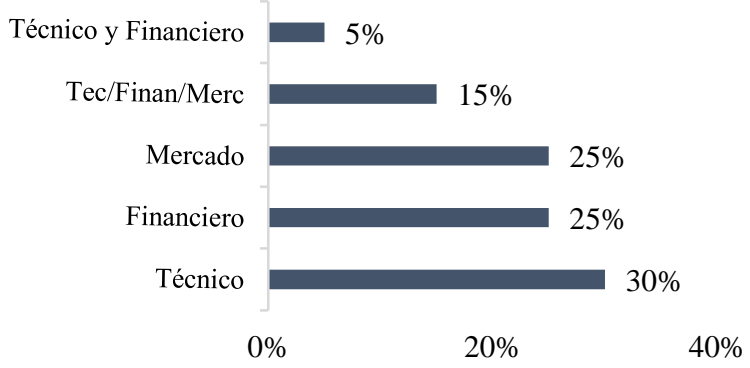

Graphic 9 Studies prior to an investment project Source: Self Made

Figure 10 shows that the main source of financing in $53 \%$ of the companies surveyed is the accumulated profits, $42 \%$ indicates the share capital and 5\% indicates that the bank's main source of financing is.

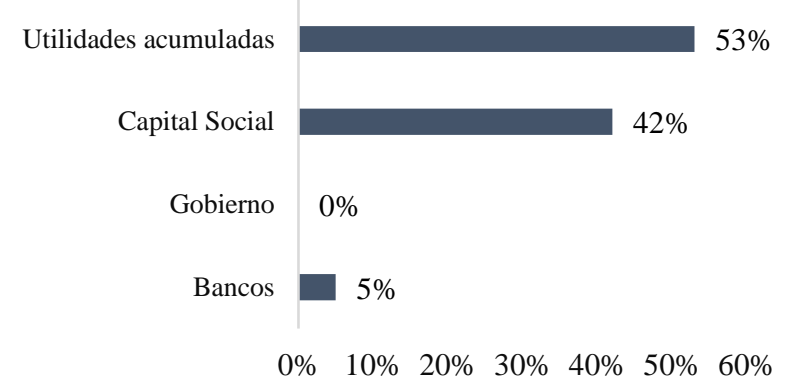

Graphic 10 Main source of financing Source: Self Made

$39 \%$ of the companies participating in the sample consider the increase in productivity as a determining factor to request financing, $29 \%$ an increase in sales, $16 \%$ business opportunities, $3 \%$ consider the three previous factors, the $3 \%$ increase in productivity and opportunities, and the remaining $10 \%$ consider other non-specific factors, as shown in figure 11.

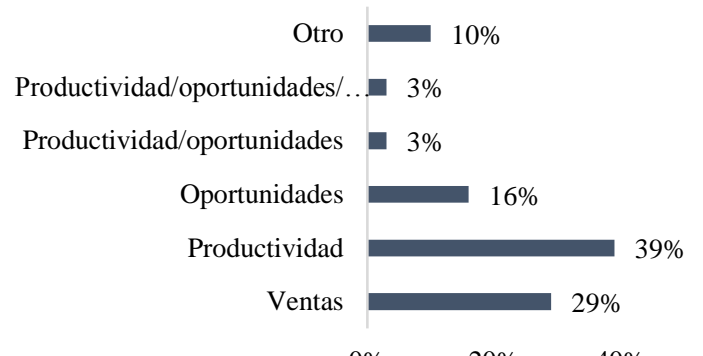

$0 \% \quad 20 \% \quad 40 \% \quad 60 \%$

Graphic 11 Factors considered when requesting financing Source: Self Made
With reference to the process to access a loan in banking institutions in Figure 12, it can be seen that $58 \%$ of the companies surveyed mentioned not having requested bank financing, $19 \%$ affirm that the process is adequate, $16 \%$ mention that it is partially adequate, while $7 \%$ consider the process not adequate.

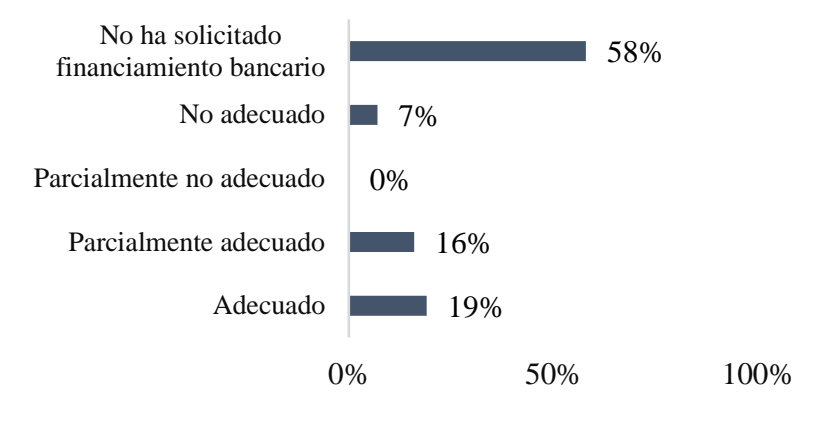

Graphic 12 Loan process in banking institutions Source: Self Made

\section{Short Term Financial Administration}

For the study of the short-term financial management indicator, the administration of cash and accounts receivable was considered. Table 6 shows that $67 \%$ of the companies participating in this study state that they perform financial management of cash through bank reconciliations, temporary investments and a minimum balance in their accounts, while 33\% responded negatively. However, only $35 \%$ of companies make monthly bank reconciliations. Regarding the existence and compliance of credit and collection policies, $77 \%$ indicate that they have this type of policy, while $19 \%$ have an absence of credit and collection policies.

\begin{tabular}{|l|r|r|r|}
\multicolumn{1}{|c}{ Question } & Yes & $\begin{array}{c}\text { No } \\
\%\end{array}$ & ND \\
\hline $\begin{array}{l}\text { Does the company make monthly } \\
\text { bank reconciliations? }\end{array}$ & 35 & 65 & 0 \\
\hline $\begin{array}{l}\text { Does the company make temporary } \\
\text { investments of cash surpluses? }\end{array}$ & 81 & 19 & 0 \\
\hline $\begin{array}{l}\text { Does the company have the policy } \\
\text { of maintaining a minimum balance } \\
\text { in bank accounts? }\end{array}$ & 84 & 16 & 0 \\
\hline \multicolumn{1}{|c|}{ Average } & 67 & 33 & 0 \\
\hline $\begin{array}{l}\text { iLa empresa tiene políticas de } \\
\text { crédito y cobranza por escrito, y se } \\
\text { cumplen? }\end{array}$ & 77 & 19 & 3 \\
\hline
\end{tabular}

Table 6 Cash and accounts receivable management Source: Self Made 


\section{Conclusions}

The results obtained in this research work allow us to conclude that in the medium-sized companies of the industrial and commercial sector in Ciudad Juárez, Chihuahua, effective financial management is carried out, since they have a healthy financial structure, with a minimum of assets financed with liabilities, which indicates that in case of some financial contingency they could overcome it since the financial commitments, in the majority of the companies surveyed are not significant.

Likewise, medium-sized companies use the financial statements as a tool for decisionmaking since these statements are mostly reviewed by a different entity to the one who prepares them, which gives them a greater degree of reliability.

It is important to consider that $61 \%$ of the companies participating in this research are 6 to 15 years old, and $23 \%$ are older than 20 years. This can be a factor that positively impacts your financial management.

Another important finding observed in the results is that medium-sized companies have or have had investment projects in the last 5 years, mostly for the acquisition of assets. This indicates that companies are growing or that they have the financial possibilities to renew their fixed assets, however, most of the investment projects are financed by own resources, either, profits from previous years or contributions from shareholders, which implies that companies are not taking advantage of external financing, for example, bank loans or financing through the stock market and therefore, the business risk leans mostly towards shareholders.

Financing through liabilities, with effective financial management has advantages such as the deductibility of interest for tax purposes and a balanced financial structure with respect to the assets of the company, so it is recommended that the sources of financing do not come in large shareholder contributions or accumulated profits. On the other hand, some authors (Rodríguez and Hernández, 2013; Urrutia and Cuevas, 2016) suggest that through the integration of business networks, competitive improvement, efficiency in processes and the social capital of companies are increased.
Under this perspective, it is considered important that medium-sized companies in Ciudad Juárez, Chihuahua, integrate business networks that aim to share best practices, carry out government and private management, as well as provide advice and training to network members, among other activities.

Finally, it is recommended to conduct studies of medium-sized companies with a focus on compliance with the requirements for bank financing, their financial capacity for timely payment of principal and interest on loans requested, as well as analyzing whether medium-sized companies They are open to financing through the stock market, which opens the possibility to obtain resources from a large number of investors at a financial cost potentially lower than the bank, complying with the legal, financial and corporate requirements established by the Law of the Stock Market.

\section{References}

Banco de México (BANXICO). (2015). Reporte sobre las condiciones de competencia en el otorgamiento de crédito a las pequeñas y medianas empresas (PYME). Disponible en: http://www.banxico.org.mx/publicaciones-yprensa/reportes-sobre-las-condiciones-decompetencia-en-1/\%7B1C74E16B-F3D9DBA7-6E7E-80C130C76599\%7D.pdf

Bolsa Mexicana de Valores (BMV). (2019). Glosario. Disponible en: https://bmv.com.mx/es/grupo-bmv/glosario

Castillo, A., y Ceballos, R. (2014). Modelo de Formalización Bursatil Para Pequeñas Empresas en Cancún Quintana Roo. Revista Global de Negocios, Vol. 2, No. 4, pp. 57-69.

Castro, Z. (2017). Evaluación de proyectos de inversión para pequeñas y medianas empresas con una estrategia de proyección financiera. Ra Ximhai 13 (3), 15-40.

Comisión Nacional para la Defensa de los Usuarios de Servicios Financieros (CONDUSEF). (2015). Empresario PYME. Como usuario de Servicios Financieros. Recuperado el 15 de abril del 2015 de http://www.condusef.gob.mx/PDF-

s/cuadros_comparativos/bancos/cuentas_credito /pymes/empresario_pyme.pdf. 
González, G. (2015) Importancia de las micro, pequeñas y medianas empresas en el desarrollo económico y la generación de empleo en México. Disponible en: http://sociologiaalas.org/acta/2015/GT-

17/Importancia\%20de\%20las\%20micro\%20peq ue $\%$ C $3 \%$ B 1 as $\% 20 y \% 20$ medianas $\% 20$ empresas $\% 20$ en $\% 20$ el\%20desarrollo\%20econ\%C3\%B3 mico\%20y\%20la\%20generaci\%C3\%B3n\%20d e\%20empleo\%20en\%20m\%C3\%A9xico.docx

Gonzales, A., y Quizhpe, J. (2012). Planeación Financiera de la Empresa. Loja.

HSBC (2019). Descubriendo el potencial de crecimiento de las empresas medianas 2017. Disponible en: http://t21.com.mx/general/2017/12/01/hsbcrevela-aporte-empresas-medianas-economiamexicana

Instituto Nacional de Estadística y Geografía (INEGI). (2019). Directorio Estadístico Nacional de Unidades Económicas (DENUE). Disponible en:

https://www.inegi.org.mx/app/mapa/denue/

Instituto Nacional de Estadística y Geografía (INEGI). (2015). Encuesta Nacional sobre Productividad y Competitividad de las Micro, Pequeñas y Medianas Empresas 2015 (ENAPROCE). Disponible en: https://www.inegi.org.mx/programas/enaproce/ 2015/

Nava, M. (2009). Análisis financiero: una herramienta clave para una gestión financiera eficiente. Revista Venezolana de Gerencia, 14 (48), 606-628.

Normas de Información Financiera (2018) Consejo mexicano para la investigación y desarrollo de normas de información financiera A.C. (CINIF). Novena edición. México: Instituto Mexicano de Contadores Públicos.

Perdomo, A. (2008). Elementos básicos de administración financiera. México: Cengage Learning.

Rodríguez, P. (2016). Gestión Financiera en PyMES. Dialnet. Vol. 3, Nº. 8, 2016. págs. 588596.
Solis, F. y Limas, M. (2013). Capital social y desarrollo: origen, definiciones y dimensiones de análisis. Nóesis. Revista de Ciencias Sociales y Humanidades. $22 . \quad 186-213$. 10.20983/noesis.2013.1.6.

Urrutia, J., y Cuevas, T. (2016). Redes empresariales en el sector turismo y servicios para la mejora de competitividad en Ciudad Juárez, Chihuahua, México: caso Parque Central Hermanos Escobar y PYMES aledañas. Cuadernos de Turismo. 421. 10.6018/turismo.37.256331. 